\title{
Burnout and academic satisfaction of nursing students in traditional and integrated curricula
}

\author{
Burnout e satisfação acadêmica em estudantes de enfermagem \\ de currículo tradicional e integrado \\ Burnout y satisfacción académica de los estudiantes de \\ enfermería del currículo tradicional y del integrado
}

How to cite this article:

Batista RS, Santos MS, Melo EC, Moreira RC, Martins JT, Galdino MJQ. Burnout and academic satisfaction of nursing students in traditional and integrated curricula. Rev Esc Enferm USP. 2021;55:e03713. doi: https://doi.org/10.1590/S1980-220X2020002003713

\section{Rafaely da Silva Batista ${ }^{1}$ \\ Márcio Souza dos Santos ${ }^{2}$ \\ Emiliana Cristina Melo ${ }^{1}$ \\ Ricardo Castanho Moreira ${ }^{1}$ \\ Júlia Trevisan Martins ${ }^{2}$ \\ Maria José Quina Galdino ${ }^{1}$}

${ }^{1}$ Universidade Estadual do Norte do Paraná, Departamento de Enfermagem, Bandeirantes, PR, Brazil.

${ }^{2}$ Universidade Estadual de Londrina, Departamento de Enfermagem, Londrina, PR, Brazil.
Corresponding author: Maria José Quina Galdino Universidade Estadual do Norte do Paraná, Departamento de Enfermagem Rodovia BR 369, Km 54 - Vila Maria CEP 86360-000 - Bandeirantes, PR, Brazil mariagaldino@uenp.edu.br

\begin{abstract}
Objective: To verify the prevalence of burnout and its relationship with the academic satisfaction of nursing students in traditional and integrated curricula. Method: Quantitative, observational, cross-sectional, and analytical descriptive study with nursing undergraduates in two public universities. The data were collected in the classroom through a characterization survey, Maslach Burnout Inventory, and the Nursing Student Satisfaction Scale, and analyzed through inferential and descriptive statistics. Results: The participants included 301 undergraduate students. The prevalence of burnout in the traditional curriculum was $30.2 \%$; in the integrated one, this was $16.2 \%$. Academic efficacy $(p=0.004)$, satisfaction with curriculum and teaching $(p=0.011)$, and professional and social integration $(p<0.001)$ were higher for students in the integrated curriculum. Satisfaction with the educational environment was higher in the traditional curriculum $(p=0.012)$. Burnout was statistically associated with low academic satisfaction in all dimensions. Conclusion: The prevalence of burnout has differed significantly among students in the analyzed curriculum models and is directly associated with academic satisfaction or lack thereof. Educators should develop preventive actions against burnout in future nurses focusing on the promotion of academic satisfaction.
\end{abstract}

\section{DESCRIPTORS}

Stress, Psychological; Students, Nursing; Education, Nursing; Curriculum; Personal Satisfaction. 


\section{INTRODUCTION}

Diverse mental disorders have been afflicting university students, who are considered a vulnerable population. Epidemiological studies show that their first symptoms manifest at the beginning of adult life, when students are in a transition period ${ }^{(1-2)}$. Health courses, aimed at educating professionals to provide care, have the most psychologically unsound students ${ }^{(2)}$, which is particularly true of nursing ${ }^{(1,3)}$. Individual, academic, and contextual variables are related to the process of resilience and illness in these individuals ${ }^{(1)}$.

Studies conducted in Brazil ${ }^{(4)}$, Italy ${ }^{(5)}$, China ${ }^{(6)}$, and Spain ${ }^{(7)}$ have evaluated burnout syndrome in undergraduate nursing students, finding a high level of exhaustion associated with low dispositional empathy ${ }^{(5)}$, a negative professional self-concept ${ }^{(6)}$, low resilience ${ }^{(7)}$, being in the first terms, taking more than 10 subjects simultaneously, and thinking of dropping out ${ }^{(4)}$. Chronic stress factors derive from specific educational characteristics, such as a high intra and extrauniversity course load, numerous academic activities to be executed within short deadlines, participation in teaching, research, and extension projects as extracurricular activities, interpersonal relations with peers and professors, and working in health services, where they face other people's suffering and fear of harming patients by causing adverse events, situations which may overload them and lead to burnout syndrome ${ }^{(3)}$.

Although university students are not considered workers, the organization and required goals of academic activities are similar to work, from a psychological perspective ${ }^{(8)}$. Academic burnout thus results from a combination of exhaustion (lack of energy) due to study demands; depersonalization, manifested through emotional apathy, lack of motivation, withdrawing from course activities and interpersonal relations; and low academic efficacy, with a negative feeling towards oneself. These dimensions are both related and independent ${ }^{(8)}$.

The stressful situations of the university environment are directly related to academic satisfaction ${ }^{(9)}$, which involves the students' perception of their educational experience in relation to teaching and curricular activities. These encompass the appropriateness of curricular content, methodology, didactics, and evaluation; professional social interaction, corresponding to interpersonal relationships with professors, students, and professionals, which are inherent to the educational process; and the teaching environment, understood as the infrastructure offered by the organization during the educational process ${ }^{(10)}$.

In this perspective, nursing curricula have been changing to increase student motivation and satisfaction and deal with psychological suffering; however, the only found evaluations of the effects of curricular changes on mental health focused on medicine courses ${ }^{(11-12)}$. Little knowledge has been produced so far on the role of educational curricula in burnout among nursing students. In this area, basically two types of curricular model are commonly used: (i) traditional, which is of a theoretical-deductive type and departs from basic scientific premises formalized into subjects, subsequently approaching practical situations, with professor-centered teaching (banking education) following conventional teaching methodologies and evaluations; and (ii) integrated, with an inductive-theoretical approach, in which general and profession-specific educational contents are combined, involving interdisciplinarity, inseparability of theory and practice, and concomitant teaching and learning between professors and students (problem-posing and liberating education) through active teaching methodologies and diversified evaluative processes based on performance or competence ${ }^{(13)}$.

Considering the consequences of burnout syndrome to the students' biopsychosocial health ${ }^{(14)}$ and the possibility of educating less empathetic recently graduated nurses, with a poorer mastery of their occupational activities and the intention of abandoning the profession ${ }^{(15)}$, it is important to analyze the relation between burnout and academic satisfaction in nursing students of different curricular models. This study's findings may support the planning of interventions to preserve student health, which may contribute to nurses who are engaged and prepared to provide quality care.

Departing from this perspective, this research aims at verifying the prevalence of burnout syndrome and its relationship with academic satisfaction in nursing students in traditional and integrated curricula.

\section{METHOD}

\section{Design OF STUDY}

This is an observational, descriptive-analytic study, with a quantitative approach and a cross-sectional design, given that the outcome and exposure were measured simultaneously.

\section{POPUlation}

The study was conducted in nursing undergraduate courses of two public state universities in southern Brazil located in the same state. The courses have a workload of 4,490 and 4,152 hours and different curricular models, with a traditional and an integrated curriculum, respectively. Both curricular designs include theoretical and laboratory classes, practice in health services, and mandatory curricular internship. The study population comprised 347 students of these courses, 146 of which were in the traditional curriculum, with other 201 in the integrated curriculum.

The inclusion criteria were regularly enrolled students over 18, with the exclusion of those who were on any type of leave from academic activities, including a domiciliary exercise regimen.

\section{SAMPLE}

Considering the population, the sample size was calculated adopting a $50 \%$ prevalence (percentage resulting in maximum sample size), 5\% significance level and an absolute sample error of 5\%, obtaining the minimum number of 182 students to compose the sample, with 77 in the traditional curriculum and 105 in the integrated curriculum.

\section{Data collection}

From November 2018 to May 2019, all eligible students of the mentioned courses were invited, and data collection was conducted in the classroom in a date and time previously 
established with the course coordinators. The undergraduate students were informed of the study object and those who agreed to participate signed the Informed Consent Form, after which they were provided with the data collection questionnaire. Hence, $116(79.4 \%)$ students in the traditional and $185(92.0 \%)$ in the integrated curriculum have participated, since 29 were under 18 and 16 people refused to participate.

The research instrument was composed of a characterization questionnaire covering demographics (age, sex, marital status, living with family, and employment status), academic information (year of admission, current term, has a scholarship, using medication due to studying, taking pending curricular component(s), and intention of giving up the course), and life conditions (performing physical activity, with frequency and duration, and having enough financial resources for their needs), the Maslash Burnout Inventory - Student Survey (MBI-SS) and Nursing Student Satisfaction Scale (NSSS).

The Student Survey version of the instrument Maslach Inventory Burnout was adapted from Maslach Burnout Inventory - Human Services Survey (MBI-HSS) by Schaufeli and collaborators. This is a self-applied 15 item questionnaire, with a seven-point Likert-type scale which evaluates the three-dimensional structure of burnout syndrome in students: emotional exhaustion, depersonalization, and academic efficacy. Its translation and validation to the Brazilian context was performed by Carlotto and Câmara ${ }^{(16)}$, and it has shown an appropriate reliability and validity.

The scores of the burnout dimensions must be divided into high and low, according to the cut points determined by the instrument's authors (high emotional exhaustion: $\geq 16$ points; high depersonalization: $\geq 11$ points; low academic efficacy: $\leq 10$ points), and their combination results in the latent profiles engaged (low emotional exhaustion, low depersonalization, and high academic efficacy), disengaged (high depersonalization only), inefficient (low academic efficacy only), exhausted (only high emotional exhaustion), and burnout (high emotional exhaustion and depersonalization and low academic efficacy) $)^{(17)}$.

The NSSS was elaborated by Chen and collaborators and validated for Brazil in 2016 through exploratory factorial analysis, with a Cronbach's alpha of $0.934^{(18)}$. This instrument is composed of 22 questions, whose answers are provided in five-point Likert scale aimed at evaluating the nursing students' academic satisfaction with three dimensions: curriculum and teaching, professional social interaction, and learning environment. The obtained scores do not correspond to a number; these are dichotomized into high and low through the median instead.

\section{DATA TREATMENT AND ANALYSIS}

The data were analyzed with the software Statistical Package for the Social Sciences (SPSS), version 22.0. The absolute and relative frequencies were calculated. The two curricular organizations were compared using Wald Chi-square test. The association between burnout syndrome (dependent variable) and academic satisfaction (independent variable) was identified through multiple models of logistic regression, considering the adjustment variables sex and age due to the suggestion from the literature ${ }^{(18)}$, in addition to characterization variables which present significant differences when curricula are compared, if these occurred at least 10 times. A p-value $<0.050$ was considered statistically significant, and the results were expressed by odds ratio and $95 \%$ confidence interval.

\section{ETHICAL ASPECTS}

All ethical aspects were respected throughout this research, which abided by Resolution n. 466/12 by the National Health Council; it was also approved by the Research Ethics Committee in November 2018 in Opinion n. ${ }^{\circ}$ 2.967.863. All participants have signed the Informed Consent Form.

\section{RESULTS}

This study comprised 301 nursing students in two curricular models, with 116 in the traditional curriculum and 185 in the integrated curriculum, whose characterization is presented in Table 1.

Table 1 - Comparison between the characteristics of nursing students per course curriculum - Bandeirantes/Londrina, PR, Brazil, 2018-2019.

\begin{tabular}{|c|c|c|c|}
\hline \multirow[t]{2}{*}{ Characterization variables } & $\begin{array}{l}\text { Traditional } \\
\text { Curriculum }\end{array}$ & $\begin{array}{c}\text { Integrated } \\
\text { Curriculum }\end{array}$ & \multirow[t]{2}{*}{ p-value } \\
\hline & $\mathrm{n}(\%)$ & $\mathrm{n}(\%)$ & \\
\hline \multicolumn{4}{|l|}{ Age } \\
\hline 18 to 20 years & $67(57.8)$ & $126(68.1)$ & \multirow{2}{*}{0.069} \\
\hline 21 to 42 years & $49(42.2)$ & $59(31.9)$ & \\
\hline \multicolumn{4}{|l|}{ Gender } \\
\hline Female & 108(93.1) & 164(88.6) & \multirow{2}{*}{0.193} \\
\hline Male & $8(6.9)$ & $21(11.4)$ & \\
\hline \multicolumn{4}{|l|}{ Marital status } \\
\hline Single & 113(97.4) & 184(95.5) & \multirow{2}{*}{0.136} \\
\hline Married & $3(2.6)$ & $1(0.5)$ & \\
\hline \multicolumn{4}{|l|}{ Lives with family } \\
\hline No & $75(64.7)$ & $43(23.2)$ & \multirow{2}{*}{$<0.001$} \\
\hline Yes & $41(35.3)$ & $142(76.8)$ & \\
\hline \multicolumn{4}{|l|}{ Has a scholarship** } \\
\hline No & 95(81.9) & $140(75.7)$ & \multirow{2}{*}{0.200} \\
\hline Yes & $21(18.1)$ & $45(24.3)$ & \\
\hline \multicolumn{4}{|l|}{ Works } \\
\hline No & 107(92.2) & 165(89.2) & \multirow{2}{*}{0.376} \\
\hline Yes & $9(7.8)$ & 20(10.8) & \\
\hline \multicolumn{4}{|l|}{ Physically active ${ }^{* * *}$} \\
\hline No & $107(92.2)$ & 175(94.6) & \multirow{2}{*}{0.419} \\
\hline Yes & $9(7.8)$ & $10(5.4)$ & \\
\hline \multicolumn{4}{|c|}{ Uses medication due to studying } \\
\hline No & $72(62.1)$ & $107(57.8)$ & \multirow{2}{*}{0.466} \\
\hline Yes & $44(37.9)$ & $78(42.2)$ & \\
\hline \multicolumn{4}{|c|}{ Takes pending curricular component(s) } \\
\hline No & $80(69.0)$ & 184(99.5) & \multirow{2}{*}{$<0.001$} \\
\hline Yes & $36(31.0)$ & $1(0.5)$ & \\
\hline \multicolumn{4}{|c|}{ Current term compatible with year of admission } \\
\hline No & 21(18.1) & $10(5.4)$ & 0.001 \\
\hline
\end{tabular}




\begin{tabular}{|c|c|c|c|}
\hline \multirow[t]{2}{*}{ Characterization variables } & $\begin{array}{l}\text { Traditional } \\
\text { Curriculum }\end{array}$ & $\begin{array}{l}\text { Integrated } \\
\text { Curriculum }\end{array}$ & \multirow[t]{2}{*}{ p-value* } \\
\hline & $\mathbf{n}(\%)$ & $n(\%)$ & \\
\hline Yes & $95(81.9)$ & $175(94.6)$ & \\
\hline \multicolumn{4}{|l|}{ Intends to give up the course } \\
\hline No & $35(30.2)$ & $73(39.5)$ & \multirow{2}{*}{0.100} \\
\hline Yes & $81(69.8)$ & $112(60.5)$ & \\
\hline \multicolumn{4}{|c|}{ Financial resources are enough for necessities } \\
\hline A little & $88(75.9)$ & $147(79.5)$ & \multirow{2}{*}{0.465} \\
\hline Mostly & $28(24.1)$ & $38(20.5)$ & \\
\hline
\end{tabular}

The participants' characteristics were similar concerning age, sex, marital status, having a scholarship, being employed, being physically active, using medication due to studying, intending to give up the course, and financial resources being enough for their needs. However, they were different regarding living with the family, which was more prevalent in students of the integrated curriculum, taking a pending curricular component, and the incompatibility of the current term with the year of admission, which was more prevalent among students of the traditional curriculum.

Table 2 shows that, among the dimensions of the burnout syndrome, high academic efficacy presented a higher proportion among the integrated curriculum students in relation to the traditional curriculum students $(p=0.004)$. Concerning latent profiles, disengagement was higher in the integrated curriculum $(\mathrm{p}=0.047)$ and engagement was higher in the traditional curriculum $(\mathrm{p}=0.043)$. The dimensions curriculum and teaching $(\mathrm{p}=0.011)$ and professional social interaction $(\mathrm{p}<0.001)$ were higher among students of the integrated curriculum in relation to the traditional. On the other hand, high satisfaction with the teaching environment was lower among integrated curriculum students in relation to the traditional curriculum students $(\mathrm{p}=0.012)$.

Table 2 - Dimensions of the burnout syndrome and academic satisfaction of nursing students per course curriculum - Bandeirantes/Londrina, PR, Brazil, 2018-2019.

\begin{tabular}{lccc}
\hline \multirow{2}{*}{ Variables } & $\begin{array}{c}\text { Traditional } \\
\text { Curriculum }\end{array}$ & $\begin{array}{c}\text { Integrated } \\
\text { Curriculum }\end{array}$ & p-value* \\
\cline { 2 - 3 } & $\mathbf{n}(\%)$ & $\mathbf{n}(\%)$ & \\
\hline Burnout syndrome & & & \\
Emotional Exhaustion & & & \multirow{2}{*}{0.065} \\
Low & $19(16.4)$ & $17(9.2)$ & \\
High & $97(83.6)$ & $168(90.8)$ & \\
Depersonalization & & & \multirow{2}{*}{0.556} \\
Low & $55(47.4)$ & $94(50.8)$ & \\
High & $61(52.6)$ & $91(49.2)$ & \\
Academic Efficacy & & & $\mathbf{0 . 0 0 4}$ \\
Low & $48(41.4)$ & $47(25.4)$ & \\
High & $68(58.6)$ & $138(74.6)$ & \\
\hline
\end{tabular}

\begin{tabular}{lccc} 
N...continuation & & \\
\hline \multirow{2}{*}{ Variables } & $\begin{array}{c}\text { Traditional } \\
\text { Curriculum }\end{array}$ & $\begin{array}{c}\text { Integrated } \\
\text { Curriculum }\end{array}$ & p-value* \\
\cline { 2 - 3 } & $\mathbf{n}(\%)$ & $\mathbf{n}(\%)$ & \\
\hline Latent profiles as per & & & \\
MBI-SS** & & & \\
Exhausted & & & \\
No & $77(66.4)$ & $105(56.8)$ & 0.095 \\
Yes & $39(33.6)$ & $80(43.2)$ & \\
Disengaged & & & \\
No & $90(77.6)$ & $124(67.0)$ & $\mathbf{0 . 0 4 7}$ \\
Yes & $26(22.4)$ & $61(33.0)$ & \\
Inefficient & & & \\
No & $113(97.4)$ & $180(97.3)$ & 0.951 \\
Yes & $3(2.6)$ & $5(2.7)$ & \\
Engaged & & & \\
No & $103(88.8)$ & $176(95.1)$ & $\mathbf{0 . 0 4 3}$ \\
Yes & $13(11.2)$ & $9(4.9)$ & \\
\hline
\end{tabular}

Academic satisfaction

Curriculum and Teaching

\begin{tabular}{lccc} 
Low & $78(67.2)$ & $97(52.4)$ & $\mathbf{0 . 0 1 1}$ \\
High & $38(32.8)$ & $88(47.6)$ & \\
$\begin{array}{l}\text { Professional social } \\
\text { interaction }\end{array}$ & & & \\
Low & $77(66.4)$ & $81(43.8)$ & $\mathbf{0 . 0 0 1}$ \\
High & $39(33.6)$ & $104(56.2)$ & \\
$\begin{array}{l}\text { Teaching Environment } \\
\text { Low }\end{array}$ & $53(45.7)$ & $112(60.5)$ & $\mathbf{0 . 0 1 2}$ \\
High & $63(54.3)$ & $73(39.5)$ & \\
\hline
\end{tabular}

*Wald's Chi-squared; **Maslash Burnout Inventory - Student Survey

In Figure 1, the prevalence of the burnout syndrome is of $30.2 \%$ in the traditional curriculum and $16.2 \%$ in the integrated curriculum, the latter of which is a statistically significant difference $(\mathrm{p}=0.004)$.

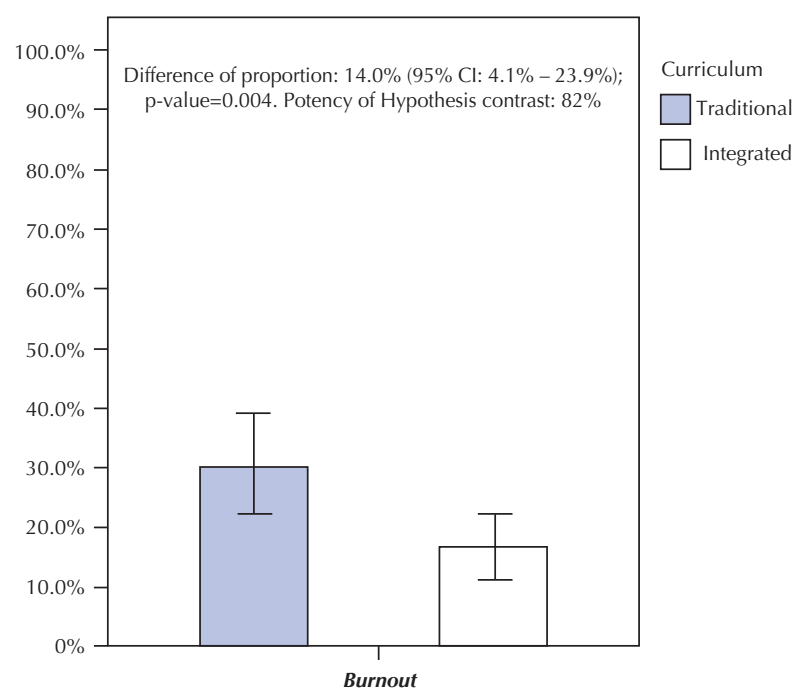

Figure 1 - Prevalence of burnout syndrome among nursing students per course curriculum - Bandeirantes/Londrina, PR, Brazil, 2018-2019. 
Table 3 shows that low academic satisfaction presented a significant association with burnout syndrome in all dimensions.

Table 3 - Association of burnout syndrome with nursing students' dimensions of academic satisfaction - Bandeirantes/Londrina, PR, Brazil, 2018-2019.

\begin{tabular}{lcccc}
\hline \multirow{2}{*}{$\begin{array}{l}\text { Academic } \\
\text { satisfaction }\end{array}$} & $\begin{array}{c}\text { No } \\
\mathbf{n}(\%)\end{array}$ & $\begin{array}{c}\text { Yes } \\
\mathbf{n}(\%)\end{array}$ & $\begin{array}{c}\text { Adjusted odds } \\
\text { ratio* (Confidence } \\
\text { Interval 95\%) }\end{array}$ & p-value \\
\cline { 2 - 3 } Curriculum and Teaching & & & \\
Low & $127(72.6)$ & $48(27.4)$ & $2.395(1.249-4.594)$ & \\
High & $109(86.5)$ & $17(13.5)$ & 1 & $\mathbf{0 . 0 0 9}$ \\
\hline Professional social interaction & & 1 & \\
Low & $108(68.4)$ & $50(31.6)$ & $3.889(1.965-7.697)$ & \\
High & $128(89.5)$ & $15(10.5)$ & 1 & $\mathbf{0 . 0 0 1}$ \\
\hline Teaching Environment & & & $\mathbf{0 . 0 0 8}$ \\
\hline
\end{tabular}

*adjusted by sex, age (in years), living with family, coursed term, current term compatible with year of admission and course curriculum

The results for the association between burnout and academic satisfaction are valid in both curricular conformations, regardless of sex, age, living with family, current term, compatibility of current term with year of admission and coursed curriculum.

\section{DISCUSSION}

In this study, the prevalence of burnout syndrome and its relationship with academic satisfaction among nursing students of the traditional and integrated curricula were verified. The prevalence of burnout syndrome was identified to differ in the analyzed curricular models and was higher than that of other students of the health area ${ }^{(12,19)}$. The integrated curriculum students presented a high academic satisfaction with the professional social interaction and curriculum and teaching, but low satisfaction with the learning environment in relation to students in the traditional curriculum. Also, low academic satisfaction was associated to burnout syndrome.

Most students were female, which was also true of studies conducted in Brazil and elsewhere, as this is a socio-historical characteristic of nursing originating from the fact that care is culturally attributed to women ${ }^{(4-7)}$. It should be also considered that exhaustion is higher among young female undergraduate students ${ }^{(7-8)}$.

Professional social interaction in the context of academic satisfaction is defined by how students relate to and communicate with the professors during the course ${ }^{(17)}$. In this study, satisfaction with interpersonal relations in the education process was higher among students in the integrated curriculum, indicating that these are in a less hostile environment, feel more respected, have tranquility to ask questions to professors who are qualified in their areas, and face fewer relational difficulties with the professors ${ }^{(10)}$.

A Brazilian study with nursing students has identified that one of the causes of higher stress and lesser satisfaction for them was their relationship with professors ${ }^{(20-21)}$. Given this, interpersonal relationships with professors may be less conflicted in the integrated curriculum, since students are the protagonists of their education, whereas professors are facilitators of this process. In the traditional curriculum, which is usually based on banking education, the professor is the possessor of knowledge, and conflicts may arise in the student-professor relation ${ }^{(22-23)}$.

The active methodology used in the integrated curriculum helps with this process of interaction, because it favors and stimulates challenging and instigating situations for students, making them the agents of education through communicative and interactive skills from the start ${ }^{(20)}$. The traditional curriculum, on the other hand, uses a passive methodology, in which the professor is responsible for conveying knowledge and the students have little autonomy to develop their skills. This absence of independent interaction leads to dissatisfaction $^{(21)}$ and, consequently, interpersonal conflicts.

In the context of education, interpersonal relationships must be improved in all curricular designs, since, in this study, low satisfaction with the professional social interaction was associated to burnout syndrome, which is corroborated by the literature, given that a friendly environment, with social support, is a factor of protection against this syndrome ${ }^{(24-25)}$.

The perception of satisfaction of academics in the integrated curriculum was also higher concerning the opportunity of development provided by curriculum and teaching, which is related to competent and qualified training to perform the profession, especially in the resolution of care problems and in the application of the nursing process to the different levels of healthcare. Such skills are acquired if the curriculum departs from the simplest concepts to most complex ones, employing appropriate methodologies and didactics, with an updated curricular content and consistency of subjects and their evaluative system ${ }^{(10)}$.

Educators must continuously seek efficient didactic methods, professional qualification, innovation, and appropriateness of educational curricula to the professional practice environment, stimulating students to be critical and reflexive, because these aspects influence academic satisfaction ${ }^{(8-10)}$ and significantly reduce the levels of burnout syndrome, as shown by the results of this investigation.

A higher satisfaction with professional social interaction and with curriculum and teaching in the integrated curriculum may explain the high perception of academic efficacy, since it refers to a positive self-evaluation of the individual's capacity in face of their deeds and realizations ${ }^{(8)}$. Thus, the institution's provision of better conditions for teaching and learning, with the objective of developing their students' skills, lead to higher security ${ }^{(8-10)}$.

In this study, satisfaction with the learning environment regarding the infrastructure offered by the institution, specially the physical and technological structure of laboratories for skills and simulation, was higher among students in the traditional curriculum, when compared to those in the integrated curriculum. However, students who reported low satisfaction with the learning environment presented higher chances of burnout syndrome. In Brazil, public teaching 
institutions, although their qualities are to be recognized, have a structural deficit, both due to bureaucracy in obtaining necessary equipment and their sparse economic resources.

Higher satisfaction with the learning environment may explain the higher proportion of engaged students in the traditional curriculum, if one considers that most items in this dimension refer to simulated practice. In this sense, clinical situations involving robotic, scenic, or hybrid simulation provide an opportunity for students to learn and develop their abilities in a safe educational environment and are related to behavioral, emotional, and cognitive engagement of the students ${ }^{(26)}$. Lack of engagement is a barrier for future nurses to reach the essential, necessary competences for advanced practices in Latin America relative to clinical care, patientcentered interdisciplinary communication, context of care, and evidence-based practice ${ }^{(27)}$.

The clinical learning environments of health services must be considered, as these equally reflect the quality of curricular structure and are a major concern in contemporary nursing education ${ }^{(28)}$. Students acquire more confidence and competence for clinical practice when supported by professors and preceptors, in addition to achieving clinical results of learning, softening the inappropriate structure of health services ${ }^{(29)}$.

Emotional exhaustion was observed to be proportionally higher among students of the integrated curriculum and depersonalization was higher in the traditional curriculum. However, this was not a statistically significant difference, indicating that, regardless of course curriculum, students are exhausted physically and mentally due to requirements of the curricular design and, consequently, they abandon academic activities, since these cause them psychic suffering ${ }^{(6,15)}$.

Exhaustion comes from the operationalization of the curricular design within short timespans, reducing rest and leisure moments and increasing stress levels ${ }^{(9)}$. Students' illnesses and dissatisfaction suggest the need for developing a strategy for institutional improvement and student support during the education process. In this perspective, emotional intelligence, i.e., the perception and evaluation of one's emotional state, may be used as a protective factor to help students control their emotions and deal with stressful situations that provoke burnout ${ }^{(30)}$.

Limitations include the cross-sectional design, which prevents the determination of cause and effect. Further studies should evaluate students longitudinally. Despite these limitations, this study's results advance knowledge and support the decision-making of education managers. Public and institutional policies must propose preventive actions against burnout syndrome in future nurses, focusing on the promotion of academic satisfaction, with the development of theoreticalmethodological conceptions of the curriculum, promotion of improvements in social support, and a learning environment that encourages creativity and overcoming difficulties of professional education. Also, this study's findings allow organizations to reevaluate their education processes and quality of teaching, observing the academic necessities of students.

\section{CONCLUSION}

The prevalence of burnout was significantly higher among participants in the traditional curriculum, especially academic efficacy or lack thereof. The integrated curriculum students presented a higher satisfaction regarding interpersonal interaction with the professors and the preparation to perform their profession that was provided by curriculum and teaching, but lower satisfaction with infrastructure and learning environment. Burnout syndrome was directly and significantly associated with low academic satisfaction.

Considering these results, managers and professors may propose and implement with academics actions to maximize student health, specially the development of preventive strategies against burnout for future nurses, focusing on the promotion of academic satisfaction.

\section{RESUMO}

Objetivo: Verificar a prevalência de burnoute sua relação com a satisfação acadêmica em estudantes de enfermagem de currículo tradicional e integrado. Método: Estudo quantitativo, observacional, transversal e descritivo-analítico com graduandos de enfermagem de duas universidades públicas. Os dados foram coletados em sala de aula por um questionário de caracterização, o Maslach Burnout Inventory e a Nursing Student Satisfaction Scale, e analisados por estatística descritiva e inferencial. Resultados: Participaram 301 graduandos. A prevalência de burnout no currículo tradicional foi de 30,2\% e, no integrado, de 16,2\%. Eficácia acadêmica ( $p=0,004$ ), satisfação com o currículo e ensino $(\mathrm{p}=0,011)$ e interação social e profissional $(\mathrm{p}<0,001)$ foram maiores entre os estudantes do currículo integrado. A satisfação com o ambiente de aprendizagem foi maior no currículo tradicional $(\mathrm{p}=0,012)$. Burnout esteve associado estatisticamente à baixa satisfação acadêmica em todas as suas dimensões. Conclusão: A prevalência de burnout diferiu significativamente entre os estudantes das organizações curriculares analisadas e está diretamente associada com a (in)satisfação acadêmica. Os educadores devem desenvolver ações preventivas contra o burnout para os futuros enfermeiros, focadas na promoção da satisfação acadêmica.

\section{DESCRITORES}

Estresse Psicológico; Estudantes de Enfermagem; Educação em Enfermagem; Currículo; Satisfação Pessoal.

\section{RESUMEN}

Objetivo: Verificar la prevalencia del burnout y su relación con la satisfacción académica de los estudiantes de enfermería del currículo tradicional y del integrado. Método: Estudio cuantitativo, observacional, transversal y descriptivo-analítico con estudiantes de enfermería de dos universidades públicas. Los datos se recogieron en el salón de clases a través de un cuestionario de caracterización, el Maslach Burnout Inventory, y de la Nursing Student Satisfaction Scale, y se analizaron mediante estadística descriptiva e inferencial. Resultados: Participaron 301 estudiantes universitarios. La prevalencia del burnout en el currículo tradicional fue del 30,2\% y del $16,2 \%$ en el integrado. La eficacia académica $(p=0,004)$, la satisfacción con el currículo y la enseñanza ( $p=0,011)$ y la interacción social y profesional $(\mathrm{p}<0,001)$ fueron mayores entre los estudiantes del currículo integrado. La satisfacción con el entorno de aprendizaje 
fue mayor para el currículo tradicional $(\mathrm{p}=0,012)$. El burnout se asoció estadísticamente con insatisfacción académica en todas sus dimensiones. Conclusión: La prevalencia del burnout difiere significativamente para los estudiantes de las organizaciones curriculares analizadas y se asocia directamente con la satisfacción o insatisfacción académica. Los educadores deben desarrollar acciones preventivas contra el burnout para los futuros enfermeros centradas en la promoción de la satisfacción académica.

\section{DESCRIPTORES}

Estrés Psicológico; Estudiantes de Enfermería; Educación en Enfermería; Curriculum; Satisfacción Personal.

\section{REFERENCES}

1. Fonseca JRF, Calache ALSC, Santos MR, Silva RM, Moretto SA. Association of stress factors and depressive symptoms with the academic performance of nursing students. Rev Esc Enferm USP. 2019;53:03530. doi: 10.1590/s1980-220x2018030403530

2. Mota ID, Farias GO, Silva R, Folle A. Burnout in college students: a considered of investigations. Motrivivência. 2017;29:243-56. doi: 10.5007/2175-8042.2017v29nespp243

3. Deasy C, Coughlan B, Pironom J, Jourdan D, Mannix-McNamara P. Psychological distress and coping amongst higher education students: a mixed method enquiry. PLoS One. 2014;9(12):e115193. doi: 10.1371/journal.pone.0115193

4. Silva RM, Lopes LFD, Beck CLC, Grazziano ES, Costa LS, Lopes VC. Demographic and academic characteristics that contribute to burnout occurrence in nursing students - analytic study. J Nurs Educ Pract. 2018;8(8). doi: 10.5430/jnep.v8n8p28

5. Ferri P, Guerra E, Marcheselli L, Cunico L, Di Lorenzo R. Empathy and burnout: An analytic cross-sectional study among nurses and nursing students. Acta Biomed. 2015;9;86 Suppl 2:104-15.

6. Wang M, Guan H, Li Y, Xing C, Rui B. Academic burnout and professional self-concept of nursing students: A cross-sectional study. Nurse Educ Today. 2019;77:27-31. doi: 10.1016/j.nedt.2019.03.004

7. Ríos-Risquez MI, García-Izquierdo M, Sabuco-Tebar ELA, Carrillo-Garcia C, Solano-Ruiz C. Connections between academic burnout, resilience, and psychological well-being in nursing students: a longitudinal study. J Adv Nurs. 2018;74(12):2777-84. doi: 10.1111/ jan.13794

8. Schaufeli WB, Taris TW. The conceptualization and measurement of burnout: Common ground and worlds apart. Work Stress. 2005;19(3):256-62. doi: 10.1080/02678370500385913

9. Smith MR, Grealish L, Henderson S. Shaping a valued learning journey: student satisfaction with learning in undergraduate nursing programs, a grounded theory study. Nurse Educ Today. 2018;64:175-9. doi: 10.1016/j.nedt.2018.02.020

10. Chen HC, Lo HS. Development and psychometric testing of the nursing student satisfaction scale for the associate nursing programs. J Nurs Educ Pract. 2012;2(3):369-73. doi:10.5430/jnep.v2n3p25

11. Slavin SJ, Schindler DL, Chibnall JT. Medical student mental health 3.0: improving student wellness through curricular changes. Acad Med. 2014;89(4):573-7. doi: 10.1097/ACM.0000000000000166

12. Lyndon MP, Henning MA, Alyami H, Krishna S, Yu TC, Hill AG. The impact of a revised curriculum on academic motivation, burnout, and quality of life among medical students. J Med Educ Curric Dev. 2017;31(4). doi: 10.1177/2382120517721901

13. Franco ECD, Soares NA, Bethony MFG. Currículo integrado no ensino superior em enfermagem: o que dizem os enfermeiros docentes. Enferm Foco. 2016;7(1):33-6. doi: 10.21675/2357-707X.2016.v7.n1.662

14. Salvagioni DAJ, Melanda FN, Mesas AE, González AD, Gabani FL, Andrade SM. Physical, psychological and occupational consequences of job burnout: a systematic review of prospective studies. PLoS One. 2017;12(10):e0185781. doi: 10.1371/journal.pone.0185781

15. Rudman A, Gustavsson JP. Burnout during nursing education predicts lower occupational preparedness and future clinical performance: a longitudinal study. Int J Nurs Stud. 2012;49:988-1001. doi: 10.1016/j.ijnurstu.2012.03.010

16. Carlotto MS, Câmara SG. Psychometric characteristics of the Maslach Burnout Inventory (MBI-SS) in Brazilian college students. Psico USF. 2006;11(2):167-73.

17. Leiter MP, Maslach C. Latent burnout profiles: a new approach to understanding the burnout experience. Burnout Res. 2016;3(16):89-100. doi: 10.1016/j.burn.2016.09.001

18. Hirsch CD, Barlem ELD, Barlem JGT, Dalmolin GL, Pereira LA, Ferreira AG. Cross-cultural adaptation and validation of the Nursing Student Satisfaction Scale for use with Brazilian nursing students. Rev Latino Am Enfermagem. 2016;24:327-45. doi: 10.1590/15188345.1053.2776

19. Assunção D, Gonçalves F, Andrade A, Gonçalves F, Rocha J. The occurrence of burnout syndrome in undergraduate health students from a private institution in the Northern region of Minas Gerais: cross-sectional study. Rev Ciênc Med Biol. 2019;18(1):15-20. doi: 10.9771/ cmbio.v18i1.27685

20. Hirsch CD, Barlem ELD, Almeida LK, Tomaschewski-Barlem JG, Lunardi VL, Ramos AM. Stress triggers in the educational environment from the perspective of nursing students. Texto Contexto Enferm. 2018;27(1):e0370014. doi: 10.1590/0104-07072018000370014

21. Alves FC, Apostólico MR, Pina-Oliveira AA, Puggina ACG. Importance of development opportunities and institutional support in nurses' academic satisfaction. Rev Baiana Enferm. 2018;32:e25470. doi: 10.18471/rbe.v32.25470

22. Scaramal DA, Dellaroza MSG, Vannuchi MTO, Haddad MCFL. Satisfaction of teachers working on the integrated nursing curriculum of a state university. Rev Enferm UERJ. 2017;25(1):e11630 doi: 10.12957/reuerj.2017.11630

23. Garcia SD, Vannuchi MTO, Garanhani ML, Sordi MRL. Internship in nursing: victories and challenges in the training of nurses. Trab Educ Saude. 2018;16(1): 319-36. doi: 10.1590/1981-7746-sol00105

24. García-Izquierdo M, Ríos-Risquez MI, Carrillo-García C, Sabuco-Tebar EA. The moderating role of resilience in the relationship between academic burnout and the perception of psychological health in nursing students. Educ Psych. 2015. doi: 10.1080/01443410.2017.1383073 
25. Noh YG. Influence of social support on the relationship between practice stress, emotional labor and burnout among nursing students. J Korean Acad Nurs Adm. 2017;23(5):461-70. doi: 10.11111/jkana.2017.23.5.461

26. Choi W, Dyens O, Chan T, Schijven M, Lajoie S, E Mancini M, et al. Engagement and learning in simulation: recommendations of the Simnovate engaged learning domain Group. BMJ Stel. 2017;3 Suppl 1:S23-S32. doi:10.1136/bmjstel-2016-000177

27. Honig J, Doyle-Lindrud S, Dohrn J. Moving towards universal health coverage: advanced practice nurse competencies. Rev Latino Am Enfermagem. 2019;27:e3132. doi: 10.1590/1518-8345.2901.3132

28. Papastavrou E, Dimitriadou M, Tsangari H, Andreou C. Nursing students' satisfaction of the clinical learning environment: a research study. BMC Nurs. 2016;15(1). doi 10.1186/s12912-016-0164-4

29. Phuma-Ngaiyaye E, Bvumbwe T, Chipeta MC. Using preceptors to improve nursing students' clinical learning outcomes: a Malawian students' perspective. Int J Nurs Ści. 2017;4(2):164-8. doi: 10.1016/j.ijnss.2017.03.001

30. Carvalho VS, Guerrero E, Chambel MJ. Emotional intelligence and health students' well-being: a two-wave study with students of medicine, physiotherapy and nursing. Nurse Educ Today. 2018;63:35-42. doi: 10.1016/j.nedt.2018.01.010 